\title{
PHONOLOGICAL ANALYSIS OF UNIVERSITY STUDENTS' SPOKEN DISCOURSE
}

\author{
Clara Herlina \\ Jurusan Sastra Inggris, Fakultas Bahasa dan Budaya, Bina Nusantara University \\ Jln. Kemanggisan Ilir III No. 45, Palmerah, Jakarta Barat 11480
}

\begin{abstract}
The study of discourse is the study of using language in actual use. In this article, the writer is trying to investigate the phonological features, either segmental or supra-segmental, in the spoken discourse of Indonesian university students. The data were taken from the recordings of 15 conversations by 30 students of Bina Nusantara University who are taking English Entrant subject (TOEFL -IBT). Finally, the writer is in opinion that the students are still influenced by their first language in their spoken discourse. This results in English with Indonesian accent. Even though it does not cause misunderstanding at the moment, this may become problematic if they have to communicate in the real world.
\end{abstract}

Keywords: phonology, discourse, spoken, conversation, accent

\begin{abstract}
ABSTRAK
Pembelajaran wacana merupakan pembelajaran penggunaan bahasa dalam pemakaian sehari-hari. Dalam artikel ini, penulis mencoba untuk menginvestigasi fitur phonology, baik yang bersifat segmantasi maupun supra-segmentasi, dalam wacana lisan dari mahasiswa Indonesia. Data diambil dari 15 rekaman percakapan dari 30 mahasiswa Bina Nusantara University yang mengambil mata kuliah tes Bahasa Inggris (TOEFL-IBT). Pada akhirnya, penulis menyimpulkan bahwa mahasiswa tetap terpengaruh dari bahasa ibu mereka saat mereka berbicara. Hasil penelitian ini merupakan Bahasa Inggris dengan aksen Bahasa Indonesia. Walaupun tidak menimbulkan kesalahpahaman pada saat ini, hal ini bisa menjadi problema jika mereka berkomunikasi di dunia luar.
\end{abstract}

Kata kunci: phonology, wacana, lisan, percakapan, aksen 


\section{INTRODUCTION}

Discourse, according to Crystal (1995) is a continuous stretch of (especially spoken) language larger than a sentence, a set of utterances which constitute any recognizable speech event. Blakemore (in Crystal, 1995) asserts that the study of discourse belongs to the study of language in use, i.e. in order to understand fully what an utterance means, one must go beyond traditional sentence grammar and include pragmatic explanations. Pragmatics is the linguistic sub discipline in which language is analyzed "from the point of view of the users, especially the choices they make, the constraints they encounter in using language in social interaction, and the effects their use of language has on the other language participants in an act of communication" (p.240).

The study of discourse, therefore, is the study of using language in actual use. In discourse based language teaching, for example, learners should be taught to communicate in a socially acceptable way. Chun (2002) mentions that learners need to know such interactional conventions as to how to ask questions politely and how to interrupt more than they need to know how to pronounce individual sounds perfectly. In other words, learners need to have phonological knowledge of the target language to be able to communicate in a socially acceptable way in that language.

Phonological knowledge of a language involves segmental and supra-segmental features. Segmental features are phonological units which consist of simple sounds, that is consonants and vowels. In English, there are 24 consonants and 12 vowels. Each segmental feature is considered to be an entity in itself and sequences of them are strung together in an utterance. Supra-segmental features, on the other hand, extend beyond one sound segment in an utterance, over longer stretches of speech. Supra-segmental features include features such as pitch, length, tempo, stress and rhythm. Collectively, the supra-segmental features are also called prosody or just intonation.

Each language has its own phonological system, including the segmental and supra-segmental features. Phonological differences between English and Indonesian have often caused difficulties for Indonesian students trying to speak English. They may be able to speak with correct grammar and lexicon, but the intonation is still following that of Indonesian. Studies by Flege (1981) and White (1981) also reported these prosodic phenomena, which have shown that some recurrent phonetic patterns in learner's productions were caused by interference or negative transfer from L1. Transfer of sounds/intonation from L1 to L2, according to Chun (2002) will result in foreign accent or more seriously misunderstanding between the speakers and the interlocutors.

In this article, the writer is trying to investigate the phonological features, either segmental or supra-segmental, in the spoken discourse of Indonesian university students. The data were taken from the recordings of 15 conversations by 30 students of Bina Nusantara University who are taking English Entrant subject (TOEFL -IBT). Since the topic of the conversation was already set up (such telephoning), the writer has limited the analysis on the segmental and supra-segmental features of the discourse. The writer will not discuss the pragmatics impact of the discourse that is the comprehensibility on the part of the interlocutors. The aim of this study is to find out which phonological features are caused by 'interference' from students' L1, that is Indonesian. This article will be organized as follows. The first part will discuss the terms such as: phoneme, word-stress, rhythm, and intonation from the theory. The second part will discuss the phonological features of Indonesian students based on the data collected.

\section{Theoretical Review}

\section{Phonemes}

In studying speech, we divide a continuous stream of sounds into small pieces that are called segments. For example the word 'man' consists of three segments, the first segment $/ \mathrm{m} /$, the second 
segment $/ \mathfrak{x} /$ and the third segment $/ \mathrm{n} /$. The different segments that bring about different meanings are called phonemes. For example, the segments $/ \mathrm{p} /$ and $/ \mathrm{b} /$ are different phoneme because if they are put in words such as 'pin' and 'bin', those words will have different meaning.

The phonemes in English consist of 24 consonant sounds and 12 vowel sounds. In contrast, Indonesian 22 consonant sounds and 8 vowel sounds (Dardjowidjojo, 2009). Contrastive Analysis believes that the sounds which are not found in language A but found in language B will constitute problems for the speakers of $A$ in learning language $B$. For instance, the sound $/ \Theta /$ as in the word 'think' is found in English but not in Indonesian will constitute a problem for Indonesian learning English.

\section{Word Stress}

Stress in words is characterized by prominence. Stresses syllables are recognized as stressed because they are more prominent than unstressed syllable. Prominence is produced by four main factors: (1) loudness, (2) length, (3) pitch, and (4) quality. Mc Carthy (2000) uses the term prominent syllable in contrast with stressed syllable, which is called isolate pronunciation, because it is the choice of the speaker to make certain words salient by giving prominence on certain syllables. For example, the word 'Japanese' has the stress on the third syllable 'JapaNESE'; but when it is put on the sentence, the prominence will shift into the first syllable ' a JApanese ship owner'; even it is not stressed if the prominence is moved like in 'SHE is a Japanese, NOT HIM'.

According to Roach (2000), stress placement in English depends on the following information: (1) the morphology of the words (simple or complex words), (2) grammatical category of the words (noun, verb), (3) the number of syllables, and (4) the phonological structures of the syllables (weak or strong). A wrong placement of stress on a word may cause 'foreign accent' or misunderstanding between the speaker and the listener. For example, the word 'present' is a noun if the stress is on the first syllable 'PREsent', but a verb if it is on the second syllable 'preSENT'. On the other hand, stress placement is not a crucial matter in Indonesian. Dardjowidjojo (2009) gives an example, the word 'memperbanyak', which has four syllables, can be pronounced 'MEMperbanyak, memPERbanyak, memperBAnyak, or memperbaNYAK, without changing the meaning.

\section{Rhythm}

Rhythm is the regular occurrence of stressed syllable in a connected speech. It is said that English has a stress-timed rhythm which implies that stressed syllables will tend to occur at relatively regular intervals (Roach, 2000; Chun, 2000; Cruttenden, 1995). Rhythm is most commonly discussed in terms of patterns of stressed vs. unstressed syllables. According to Roach (2000) the stress-timed rhythm theory states that the times from each stressed syllable to next will tend to be the same, irrespective of the number of intervening unstressed syllable. For instance, in the sentence:

$$
\begin{array}{lcccr}
1 & 2 & 3 & 4 & 5 \\
\text { 'Walk !'down the !'path to the! 'end of the ca!'nal }
\end{array}
$$

There are five units of rhythm. Mc Carthy (2000) adds that the impression of rhythm may arise out of a feeling of alternation between strong and weak syllables in various patterned recurrences, as in the following examples:

'Most of the "people were "visitor.

A 'friend of 'mine has 'bought a 'boat. 
Unlike English, Indonesian has syllable-timed rhythm in which the beat is determined by the number of syllables in the utterance. Each syllable is given the same amount of time and loudness. As a result, Indonesians tend to stress every syllable in an utterance (Dardjowidjojo, 2009).

\section{Intonation}

According to Dardjowidjojo (2009) intonation is the melodic rise and fall of pitches that a human uses to express his meaning or feeling through language. Theoretically, Chun (2000) says that there is no limit to the number of different pitch contours that can be produced, but not all the pitch variations in a language are significant. Halliday (1967) list five significant intonation choices.
1. Falling
2. Rising
3. Falling rising
4. Rising falling
5. Level $\rightarrow$

It is possible to divide a speech into small units in which each unit has one nuclear prominence. Each unit will be marked by some variation in pitch, either rising or falling. Such units are called tone units or tone groups. Tone units are usually separated by pauses. For example, in the sentence:

\section{'On my way to the station / I met a man'}

There are two tone groups. In the first group, the tone is falling- rising (on the word station) and in the second group the intonation is falling (on the word man).

\section{RESULTS AND DISCUSSION}

This part discusses the findings from the recordings of 30 conversations of 60 students of Bina Nusantara University. The topic of conversation is about telephoning in which the students should ask for someone's telephone number or write a message. The discussion is divided into several parts: pronunciation, stress placement, rhythm and intonation.

\section{Pronunciation}

From the data collected, most of the students still have problems in pronouncing consonant clusters and vowels. For example the word 'eight' has different variations /eig/; /aik/; /eg/. Cluster [ght] seems confusing since students were not sure whether they have to pronounce the $/ \mathrm{g} / \mathrm{or}$ not. This also happens for the word 'through' / ru:/ in which the final cluster [gh] is pronounced and the initial cluster [th] is changed into /t/, therefore the pronunciation of 'through' became /trog/, /trug/ or /troug/ or /trou/. One student even mispronounced it into/tur/. Another example is the word 'engaged' /ingeidzd/ which was pronounced /endzed/ or /engged/ by the students.

\section{Prominence}

For one syllable words, such as numbers, the stress is put on every syllable. Such as 'eight 'three- 'six - 'five - 'nine - 'one. For two-syllable words, the stress tends to be put on the last syllable, such as Ze'ro - se'ven - bi 'nus - Her 'dy - num'ber - text'book. 
The above examples show that most students were influenced by their first language, Indonesian, because most Indonesian words have the stress on the second syllables. This tendency is still carried on in the discourse level. In the following three sentences: I want to ask your company's telephone number; I want to cooperate with your company where you work; I will call your company tomorrow.

The word 'company' (which has the primary stress on the first syllable, should be pronounced as 'company) in those three sentences are stressed on the last syllable [compa'ny] irrespective of their position in the sentence. Misplacement of word stress also occurs in the word 'number' ['number] in which almost all students say it [num'ber]. Even when the stress should be shifted to the first word in 'telephone number, they still say it telephone num'ber.

\section{Rhythm}

Related to the stress placement on the last syllable, the rhythm unit of the students' discourse is also following that pattern. Look at the following examples: (1) I'm afraid! he is not here! at the moment!; (2) Hi Anton! It's Habibi! from Binus!; (2) I'm Gilbert! From Police Department!

Unlike English in which the rhythm unit begins with the stressed syllables, in Indonesian a rhythm unit ends with stressed syllables.

\section{Intonation}

In the students' discourse, they use both affirmative as well as interrogative sentences. In affirmative sentences, the division of tone groups is similar to the rhythm pattern. Tone groups are separated by pauses, so sentence above is divided into three groups.

\section{I'm afraid! he is not here! at the moment!.}

The first and second group (afraid and here) have level intonation and the last one (moment) has falling intonation.

Sentence below is also divided into three tone groups, but the intonation contours are slightly different.

$$
\text { Hi Anton! It's Habibi! from Binus! }
$$

Another intonation contour is found in the following sentence:

$$
\text { You can get it back! at the police department ! near your office. }
$$

The tendency to raise the pitch at the end of the questions occur almost in all interrogative sentences, either in yes no questions or Wh-questions. For example:

Do you have Wati number?

What's that?

When we together study for exams? 
Obviously, the students use their L1 intonational pattern when they are saying questions, especially wh-questions. In English a wh-question usually has a falling intonation.

\section{CONCLUSION}

In the phonological analysis of the university students' spoken discourse, there are several characteristics: (1) they have difficulty in pronouncing consonant cluster, such as /gh/ and determining the vowel sounds; (2) the word stress is often put at the last syllable and does not change even when the word is put in larger units (phrases and clauses); (3) the rhythm patterns are following the stress placement, so one rhythm unit ends with a stressed syllable; (4) there are some irregularities of the intonation contour for affirmative sentences; while questions tend to be pronounced with rising intonation. Finally, I am in opinion that the students are still influenced by their first language in their spoken discourse. This results in English with Indonesian accent. Even though it does not cause misunderstanding at the moment, this may become problematic if they have to communicate in the real world.

\section{REFERENCES}

Chun, D. M. (2002). Discourse intonation in L2. Philadelphia: John Benjamins.

Cruttenden, A. (1995). Intonation. Cambridge: Cambridge University Press.

Crystal, D. (1995). The cambridge encyclopedia of the English language. Cambridge: Cambridge University Press.

Dardjowidjojo, S. (2009). English phonetics \& phonology for Indonesians. Jakarta: Yayasa Obor Indonesia.

Flege, J. (1981). The phonological basis of foreign accent: A hypothesis. TESOL Quarterly 15, 443455.

Mc.Carthy, M. (2000). Discourse analysis for language teachers. Cambridge: Cambridge University Press.

Roach, P. (2001). English phonetic and phonology: a practical course. Cambridge: Cambridge University Press.

White, C. (1981). Tonal pronunciation errors and interference from English. Journal of the Chinese Language Teachers' Association 16, 27-56. 